\title{
PPP6C Gene
}

National Cancer Institute

\section{Source}

National Cancer Institute. PPP6C Gene. NCI Thesaurus. Code C102901.

This gene plays a role in both protein dephosphorylation and signaling. 